\title{
Get 'em While They're Young: Complex Digitally-Mediated Tasks for EFL Learners in Primary Schools
}

\author{
Celestine Caruso \\ University of Cologne \\ Judith Hofmann \\ University of Cologne \\ Andreas Rohde \\ University of Cologne
}

\begin{abstract}
We suggest that complex tasks can be introduced to learners as early as primary school level with the help of digital media in the form of different apps. As a theoretical basis, we will first outline the principles of teaching English in (German) primary schools. Secondly, we will look at the framework of Task-Based Language Teaching (TBLT) according to Nunan (2004) and explore how digitally-mediated tasks can be connected to this framework. Then, we will look at complex tasks as outlined by Hallet (2011) and present an example of a complex digital task for young English as a Foreign Language (EFL) learners that we developed and tested in a German primary school classroom. It is suggested that TBLT at primary level is a motivating alternative to playful teaching techniques traditionally championed at primary level. Moreover, it may be a way of bridging the problematic gap between primary and secondary level as tasks can prepare young learners for the challenges they will face at secondary level.
\end{abstract}

\section{Résumé}

Nous suggérons que des tâches complexes peuvent être présentées aux apprenants dès l'école primaire à l'aide des médias numériques sous la forme de différentes applications. Comme base théorique, nous exposerons d'abord les principes de l'enseignement de l'anglais dans les écoles primaires (en Allemagne). Ensuite, nous examinerons le cadre de l'enseignement des langues basé sur les tâches de Nunan (2004) et nous étudierons comment les tâches à médiation numérique peuvent être reliées à ce cadre. Ensuite, nous nous pencherons sur les tâches complexes telles que décrites par Hallet (2011) et présenterons un exemple de tâche numérique complexe pour de jeunes apprenants d'anglais langue étrangère que nous avons développée pour et testée dans une classe d'école primaire allemande. Il est suggéré que le TBLT au niveau primaire est une alternative motivante aux techniques d'enseignement ludiques traditionnellement défendues au niveau primaire. De plus, cette méthode peut être un moyen de combler le fossé problématique entre l'école primaire et secondaire, car les tâches peuvent préparer les jeunes apprenants aux défis qu'ils devront relever au niveau secondaire. 


\section{Get 'em While They're Young: Complex Digitally-Mediated Tasks for EFL Learners in Primary Schools}

\section{Setting the Ground: TBLT, Digital Media, and Primary Schools}

The focus on meaning is a basic principle of tasks in task-based language teaching (TBLT) and a quality criterion for what constitutes a good task. Coincidentally, this focus on meaning, as well as other aspects of pedagogical tasks defined by Nunan (2004), such as learner-centeredness and the connection to the everyday lives of learners, is also at the core of communicative and playful teaching approaches, which are employed in Teaching English as a Foreign Language (TEFL) in (German) primary schools.

Despite the fact that there seems to be no official framework or agreement on what exactly TBLT in primary schools should look like, "teachers may have at least an implicit understanding of tasks and [...] they may have used task-like activities for many years" (Dreßler, 2018, p. 121). Whereas primary school teaching of EFL can be characterised as meaning-oriented and playfully communicative, in secondary school, and especially in German grammar schools, the focus suddenly shifts from meaning and more towards forms. One way of bridging the gap between primary and secondary EFL teaching methods is by implementing the same task formats in both school types, and here, we suggest socalled complex tasks which are by definition problem-oriented (Hallet 2011), while at the same time focusing on meaning and communication. This implies on the one hand that problem-oriented task formats are introduced in primary schools, in order to prepare learners for the more form-focused teaching methods they will face in secondary school. On the other hand, these tasks allow secondary schools to shift towards a more meaningoriented, task-based approach of English language teaching (ELT).

It is, however, sometimes assumed that problem-oriented tasks and even task-based language teaching, in general, overtax young EFL learners and teachers alike: especially young learners lack the L2 knowledge and, possibly, the cognitive skills in order to tackle these tasks, and teachers are overburdened with including innovative teaching formats into their classrooms (Carless 2002, 2004, Rohde, 2016). We would like to challenge this assumption, as there are ways of adapting complex tasks to the prerequisites and needs of primary school education. One way of adapting tasks to the needs of the pupils is, we argue, by embedding them in digital learning environments. The implementation of digital media can be useful as the complexity of tasks can be easily accommodated to the different learning levels and needs of the learners (Dausend \& Nickel, 2017; Hofmann, 2018).

In doing so, another challenge of teaching in the $21^{\text {st }}$ century can be addressed: introducing digital media into (language) teaching at an early learning age, and thus, continuously fostering digital literacy. If digitally-mediated problem-oriented tasks are introduced as early as possible, for example, from first grade on, learners will acquire tasksolving strategies that could ease the transition from primary to secondary school methods.

In the first part of our paper, we will focus on the situation of Teaching English as a Foreign Language (TEFL) in German primary schools. TEFL is a fairly new subject for primary school education, making its official debut only in 2003. Since then, there has been an ongoing debate about the benefits and challenges of TEFL in primary school and when is the best time to start TEFL. We will then turn our attention to the gap between primary and secondary school levels in Germany, and more precisely, to the difference in 
teaching methods between the two levels, which can generally be characterized as a focus on meaning (playful, communicative teaching without any explicit grammar instruction) vs. a focus on form( $s$ ) (grammar-focused teaching). ${ }^{1}$ We believe that TBLT offers a way to bridge this gap, as we will lay out in this section. ${ }^{2}$

Using the previous sections as a basis, we will then look at TBLT and digital media. We will explore how this combination can be used to tackle the challenge of preparing learners for a life in a digitalized world and, at the same time, providing teachers with a framework for including digital media in their foreign-language classrooms. The socalled complex task (Hallet, 2011), which is a task type that is based in TBLT, uses problem orientation as a main feature. We believe that this task type can, on the one hand, be combined very well with digital media, and, on the other hand, be scaled up and down in complexity in a way that allows its use already in primary school. Finally, we will illustrate these ideas with a concrete example.

\section{The Dilemma of EFL at Primary Level in Germany}

Despite differences among the federal states,${ }^{3}$ in the past, pupils across Germany did not start to learn English as a foreign language (EFL) at school until the 10 years of age when they entered fifth grade at the secondary level. In 2003, the first primary schools in Germany introduced English, and since the school year 2004/2005, English (as well as French in a couple of border regions near France) has been a compulsory school subject across Germany (Wilden \& Porsch, 2020, p. 192). In twelve of the sixteen federal German states English is introduced in Grade 3 (age 8), in the four remaining states it starts in Grade 1 (age 6). However, in North Rhine-Westphalia, the most populated federal state, EFL will be pushed back to Grade 3 for the 2021/22 school year, following BadenWuerttemberg, another significant state due to its size, which also moved back the introduction to EFL from Grade 1 to Grade 3 in 2018. The reasons for this backward move in two of the three most populated federal states will be briefly discussed in the following section as they reflect different intriguing facets of a widespread skeptical attitude towards language learning in Germany.

A number of large-scale studies have shown that children generally reach the scheduled A1 level of the Common European Frame of Reference (CEFR) (BIG, 2015) and $20 \%$ of the children even surpass it (Müller, 2017, Kolb \& Legutke, 2019). However, there appears to be some general dissatisfaction with setting the goal at A1 for the first four years ${ }^{4}$ of schooling as students at secondary level are supposed to move from A1 to A2 and from B1 to B2 at the end of Grade 12 at grammar school. In other words, the expectations for English at the primary level appear to have been set too low and formal guidelines pertaining to competence levels according to which secondary school requirements and expectations are oriented are lacking in the case of primary education. (Wilden \& Porsch 2020, p. 196)

One of the issues that has arisen in connection with starting EFL in Grade 1 has been the rate of learning. A couple of studies seem to suggest that late EFL starters catch up with early EFL starters, thus rendering the early start obsolete. In an extensive study, Jaekel et al. (2017a) found that early starters (Grade 1) had an advantage over late starters (Grade 3) at Grade 5 in secondary school with regard to their reading and listening skills. 
However, by Grade 7 the late starters had prevailed, having caught up with, and even surpassing, the early starters with regard to the respective skills.

Interestingly, the follow-up study by Jaekel et al. (2017b) found that the early starters, who had been surpassed by the late starters with regard to their reading and listening skills in Grade 7, achieve better results than the late starters in Grade 9 (cf. also Kolb \& Legutke 2019, p. 10). This is particularly intriguing as it may point to long-term effects of an early EFL start that have as yet not been considered. However, it is doubtful whether critics' attitudes might change even when presented with unambiguously positive empirical results as there are further reasons why an early start for EFL may not be the future. $^{5}$

How well do English teachers succeed in bridging the gap between elementary and secondary school? Continuity of instruction at the transition to secondary level has been a hot topic in educational science and administration for some time now. From a range of countries, reports [...] and studies/reviews [...] underline three main problems at the elementary-secondary interface: secondary teachers systematically underestimating the knowledge and abilities of their new students; curricular objectives and learning content not being properly aligned between the elementary and secondary schools; and a mutual lack of acceptance of differences in teaching methods (Baumert et al., 2020, p. 32).

For many decades, EFL had been introduced in Grade 5 at the secondary level, which meant that all students started at the same point and as such it was easy to establish a language course with a strong focus on forms, ranging from simple to more complex grammatical forms (as distinguished by Pienemann 2006), which is well documented in the secondary level textbooks. Although currently, many grammar school teachers employ communicative teaching methods, it is safe to say that the focus on forms is still a notable characteristic of German grammar schools (as can be witnessed in the filmed lessons on the DVD accompanying Thaler, 2012, see also below).

In addition, grammar school English has, unlike EFL at lower secondary schools, never come under criticism for a lack of success. According to the DESI study (DESIKonsortium, 2008), students completing grammar school show the expected results in all four language skills as well as in intercultural competence, text production and language awareness. It is not surprising then that grammar school teachers represent a strong lobby in Germany and have, in the past twenty years, never seen fit to change their overall teaching style (Böttger, 2009). A new study by Baumert et al. (2020) even provides strong evidence that "secondary-level English instruction failed to respond adaptively to students" different proficiency levels at entry to the school. These problems seem most pronounced in Gymnasium schools [German grammar schools]" (p. 33).

The reasons why the German secondary school system fails to adequately respond to primary school English are due to a range of phenomena. For instance, "institutional objectives, school timetables, and class grouping arrangements in secondary schools have not generally been adapted to account for early-start students and their longer prior exposure times" (Baumert et al., 2020, p. 35; see also Hempel et al., 2018). Secondary school books have only recently been revised (around 2015) but are still based on curricula that were issued between 2003 and 2007. Thus, what is covered in primary school is 
ignored. (e.g., North Rhine-Westphalia: https://www.schulministerium.nrw.de/docs/Schul system/Medien/Lernmittel/index.html or Baden-Wuerttemberg: https://www.lsbw.de/,Lde/Startseite/ Service/sbz3; Baumert et al., 2020, p. 35). In addition, the national education standards for English at the secondary level for all the federal states have been left untouched since 2003 (KMK, 2005) which is further evidence that EFL follows "routines that were established when all students started to learn English on entering secondary school" (Baumert et al., 2020, p. 35, see also Muñoz et al., 2015).

\section{Bridging the Gap Between Primary and Secondary Level}

In this section, we would like to elaborate on the aforementioned "difference in teaching methods" between primary and secondary level. In general, this difference can be characterized as a focus on meaning vs. a focus on form $(s)$ : despite differences in the curricula of the different federal states, there is the consensus that English at the primary level should generally be playful, e.g., featuring storytelling, songs and games, and avoiding explicit grammar instruction, whereas English at the secondary level is more form-focused (Elsner, 2015; Rohde et al., 2018).

In contrast to focus on form, in which the pupils' attention is drawn on linguistic aspects when they occur naturally while solving the task, focus on forms involves "the preselection of specific features based on a linguistic syllabus and the intensive and systematic treatment of those features" (Ellis et al., 2002, p. 420.). The latter often result in teaching grammar with a Presentation Practice Production (PPP) approach (Müller-Hartmann \& Schocker, 2018; Niemeier, 2017). One explanation why PPP, instead of learner-oriented approaches, is used to teach grammar in secondary schools is provided by studies (e.g. Appel, 2000; Cameron, 2001; Müller-Hartmann \& Schocker, 2018), which found that many teachers in the German secondary EFL classrooms

"tend to view grammar as a set of structured building blocks that need to be explicitly taught $[\ldots]$, therefore taking a grammar-centred perspective of language teaching rather than a learning-centred view that understands learning as an active construction process in which learners are encouraged to diversify their developing internal grammars" (Müller-Hartmann \& Schocker, 2018, p. 103).

Furthermore teachers, especially non-native teachers of EFL, seem to resort to a rather controlled, authoritative approach to teaching where they prefer solving problems themselves rather than engaging their students in problem-solving activities (MüllerHartmann \& Schocker, 2018, p. 101). Apart from the unpredictability of tasks that seems to feed to teachers' insecurities, the obligatory EFL coursebook-based syllabus that teachers have to stick to as well as current assessment and evaluation practices are the main reasons for the lack of TBLT in secondary schools (Niemeier, 2017, p. 25).

While a focus on form(s) does not explicitly exclude playfulness or communicative teaching methodology, the national standards for secondary level include very clearly formulated objectives that include, for example, the productive mastery of grammatical phenomena (simple present vs. progressive, simple past, do vs. does, genitive -s) (MSWNRW, 2007, p. 23). Thus, it becomes obvious that the change in teaching methodology is accompanied by a change in expected content/grammar knowledge. What is required for 
both primary and secondary level, then, is a teaching approach that unifies both student and curricular needs and is, at the same time, communicative and motivating.

Mayer et al. (2012) introduced two types of Bridging Tasks. These tasks do not yet imply a reliance on a TBLT framework but share characteristics of tasks in the TBLT sense as they are product-oriented and meaning-focused. Under the heading of Primary Secondary Loop, for example, children prepare a presentation on a given topic such as "My ideal teacher" or "My object, my memories" featuring a selected object while still at primary level. These presentations can be created with a look towards secondary level and the sentence structures that are relevant in fifth grade. These can be focused on in the writing process as early as primary school. Another type of task is the Primary-Secondary Cooperation (Pri-Sec-Co) in which primary school students get in touch with a secondary school student and develop their own stories together. The primary school children start out with a beginning of a story, the so-called "model story". These model stories are passed on to secondary students who are then asked to finish the stories. This allows the students to discuss in which tense stories are usually written. Once the stories are finished, they are sent back to the primary level students (Kolb et al., 2012). Children can then, amongst other issues, discuss the past tense with which they are already familiar through storytelling. Kolb et al. also propose cooperation between primary and secondary level teachers, which has proved motivating for both sides, according to Kolb et al.

Both the bridging tasks and the Primary-Secondary Cooperation underline the fact that task formats are the most promising choice for either side of primary and secondary level, suggesting a more unified trajectory, capable of easing the transitions. Eventually, it would be desirable to give primary schools more responsibility, especially with regard to the CEFR objectives (see above). This would include a more decided focus on form as early as primary level. Secondary schooling, on the other hand, would strongly profit from moving away from a "focus on forms" (which is still pursued in many German schools despite the fact that the more recent textbooks suggest more communicative work) to a focus on form which would be more in line with communicative tasks according to TBLT.

Although primary school EFL teaching in Germany is defined by a playful, meaning-oriented and communicative approach, it is not task-based (Dreßler, 2018). However, TBLT concepts and examples have been proposed for TEFL primary school settings (e.g., Hofmann, 2018). Additionally, and on a more political level, the agency for quality and support management for schools in North Rhine-Westphalia has put forward teacher training concepts that include TBLT (QUA-Lis NRW, 2008) and a task-supported methodology for primary school settings, providing examples for information-gap tasks, opinion-gap tasks and a Storyline Approach (QUA-Lis NRW, 2020). These concepts are, however, not implemented in the curriculum.

\section{Digital Media and TBLT}

In addition to the discontinuity between primary and secondary level with regard to teaching concepts, learners and teachers have to face additional challenges, such as coping with the constantly changing requirements arising from digital and technical developments, which became particularly visible during the forced digitalization of school (and university) teaching in times of the COVID-19 pandemic. But even before COVID-19, there was a gap between expectations of policymakers and the realities teachers and 
learners are confronted with. The Digital Competence Framework for Educators (DigCompEdu) (Redecker, 2017) for example, published by the European Commission, addresses all levels of education, from educators of early childhood to adult education in both formal and informal contexts and explains what it means to be digitally competent. Defined as a conglomerate of 22 (sub)competences in 6 areas, the framework focuses on the competences needed for enhancing teaching innovation and learning environments with digital technologies.

Similarly, according to the digital strategy of the Conference of the Ministry of Cultural Affairs, schools (not only) in Germany are supposed to prepare young people for a life in a digitalized environment and teachers are supposed to make use of the potentials of digital media for teaching and learning (KMK, 2016, p. 25). These expectations, however, clash with the realities in schools, which often neither have the technical infrastructure nor the necessary overall concepts to include digital learning environments in daily lessons. In addition to infrastructural shortcomings, according to a study by Schmid et al. (2017), teachers report that they consider digital media to be a challenge they are not prepared for. At the same time, young learners do not feel prepared enough for an uncertain digital future. They acquire most of their digital skills through friends and in informal contexts, e.g., in their leisure time (DIVISI, 2018, p. 14). That the mere habit of using digital media does not automatically lead to digital literacy and the ability to critically deal with contents of the media world, seems to be out of the question, as both digital environments and digital competence are far too diverse and complex (cf. Zerweck, 2009, p. 255, who discussed this in a similar way in the context of TV). Here, school education needs to provide a safe space in which young learners are prepared for life, or in other words can become digitally competent, in an increasingly digitalized world.

While both the DigCompEdu and the curricular demands provide a point of orientation for what it means to be digitally competent and to deal with the challenges of the digital world, they nonetheless fail to explain how exactly digital media can be beneficial for individual school subjects and, in our case, TEFL. In order to close this gap between expectations and reality and prepare pupils for a rapidly evolving digital environment, we have to familiarize teachers (in training) with educational concepts of how to meaningfully integrate digital media in their future learning arrangements.

At the same time, it is necessary to familiarize pupils with the digitalized world they are taking part in as early as possible, i.e., in first grade. In the context of foreign language teaching, the question of how digital media can be embedded in the classroom context was answered by several researchers with the same methodological framework: task-based language teaching (Biebighäuser et al., 2012; Dausend \& Nickel, 2017; González-Lloret \& Ortega, 2014; Rohde et al., 2018). TBLT serves as a framework that connects the possibilities of the digital world with principles of foreign language teaching, in our case in the form of digitally mediated tasks. Here, especially the internet creates environments, in which young learners are agents in a digital world and actively engage in “'doing things' through technology-mediated transformation and creation processes, rather than just reading about language and culture in textbooks or hearing about them from teachers" (González-Lloret \& Ortega, 2014, p. 3).

As with any other task, digitally-mediated tasks need to be carefully prepared according to the principles of TBLT. For our context, we rely on the definition proposed by David Nunan (2004), in which a (pedagogical) task in the EFL classroom refers to 
classroom work that does not primarily focus on language but presents authentic problems to the learners, who need to negotiate meaning with each other and experiment with language in order to solve the task. It provides not only language-centered but also general learning opportunities as the learners generate their own meaning while solving the task. Learners are actively involved in learning, are self-directed rather than teacher-directed and are encouraged to transform knowledge through action and reflection (experiential learning, Nunan, 2004, p. 12-13). Digitally-mediated tasks should not only follow the principles of a "good" task according to TBLT, but the possibilities of the digital world can serve as an innovative addition to traditional materials included in the EFL classroom.

According to the TBLT definition proposed by Nunan (p. 1-2), tasks need to be open so that learners can create their own solutions, based on their linguistic, cognitive and motivational skills. However, pupils can only profit from the openness (and inclusive teaching potential) of a task if the presented content does not overburden them and can be connected to the linguistic and non-linguistic abilities of the learners, e.g., by suitable scaffolding. Scaffolding serves as a temporary support system and enables learners to cope with potentially overburdening tasks/task components/language by linking with and building on what children bring into the classroom in terms of language, culture, understandings, etc. (Gibbons, 2002, p. 139). This means that lessons and materials should be prepared in a way that supports learners in understanding the task (input scaffolding) and offers them the linguistic and non-linguistic means to create their own solution in the form of linguistic output (output scaffolding, Gibbons, 2002). Examples of scaffolding may include drawings or images, charts, term explanations, linguistic chunks or even verbal interaction between student and teacher. Digital tools offer a diverse set of input and output scaffolding that facilitate individual task-solutions, for example, with the help of digital dictionaries, explanatory videos, automatic reading options, recorded voice, animations, and drawings. Nevertheless, teachers should prepare additional scaffolds to make linguistic and cognitive demands more transparent for the learners, depending on the individual needs of the classroom members. In a prevailing monolingual paradigm, in which the foreign language serves as the main communicative means in the classroom, EFLbeginners in primary school especially need scaffolding to tackle EFL tasks.

Furthermore, like any other tasks, digitally-mediated tasks need to be cooperative and learner-centred (Nunan, 2004, p. 14) and should have an authentic connection to pupils' lives and interests (Ellis, 2018, p.13). With regard to authenticity, digital media offer genuine materials that are taken directly from the digital or medial world the learners are well acquainted with from their everyday lives. This implies a close connection between the language used in the pedagogical (and simulated) language environment that the classroom represents and the unaltered, un-simplified one of the digital world where English is still the lingua franca.

Digital task outcomes reflect the individual linguistic, motivational, imaginative efforts, to name but a few, that the pupils produced while dealing with the task. Through individual solutions that include multimodal digital elements as, for example, videos, animations or e-books potentially unpredictable, creative (linguistic) outcomes are produced. Especially so-called "story-making apps" (Dausend \& Nickel, 2017, p. 185), such as Puppet Pals or Book Creator that we will present in the next section, every taskoutcome is different, as it carries "the fingerprint of the learners" (Schratz \& WestfallGreiter, 2010, p. 26, translated from German by the authors). The aspect of authenticity is, 
furthermore, increased by the immediate disposability of, for example, posted tweets, uploaded videos, news headlines or images that become accessible for the classroom potentially seconds after their publication. In return, also created or modified digital task outcomes can be reposted and uploaded onto the internet, thus contributing to a digital discourse in which the learners become agents not only in the digital world but also in the classroom and are consequently taken seriously in their roles as foreign language learners. At the same time, chosen aspects of digital competences that are relevant for the task can be integrated into the EFL-classroom, as for example, information and data analysis, interpretation or critical evaluation of information found on the internet, to name but a few sub-competences from the DigCompEdu (Redecker, 2017, under Section 6: Facilitating Learners' Digital Competence).

Consequently, we understand digitally-mediated tasks as tasks that employ the general framework of TBLT with its quality-criteria, and, at the same time, make use of digital media. This does not necessarily mean that every aspect of the task is digital, but that digital media are an organic part of the task setting, e.g., as a medium for gathering information, for producing texts (in a wide sense), or for scaffolding. Again, not all of this has to be realized through digital media; it is also perfectly fine, for instance, to have a task instruction on a 'traditional' worksheet, while the task's outcome is a digital text, and the scaffolding is both analogue and digital (e.g., chunks on a worksheet combined with instruction videos). Ideally, every medium contributes in a way that suits best to solve the problem at hand, similar to real-life situations. This is in line with the claim that traditional, 'analogue' skills and literacies ${ }^{6}$ are not replaced by digital skills/literacies, but that they complement each other (cf. Jenkins et al., 2009, p. 29; O'Brien \& Scharber, 2008, p. 66). In the next sections, we will show how this understanding of digitally-mediated tasks can be realized.

\section{A Complex Digitally-Mediated Task for the Primary School Classroom}

As we have outlined in the first part of this paper, TBLT can be used to bridge the gap between primary school and its focus on meaning and secondary school and its focus on form(s) while at the same time being suited for integrating digital media into its framework. Especially, but not solely, in the context of TEFL in Germany, this means that we need to develop and use tasks that are output-oriented while helping learners to foster different kinds of literacies at the same time, adding the literacies in a cumulative learning process. For secondary schools, Hallet (2011) has developed the so-called "Komplexe Kompetenzaufgabe", which literally translates as 'complex competence task'. We will refer to it as a complex task here, as the task type is based on principles of TBLT (cf. Hallet, 2011, pp. 145) and we believe that if the quality criteria of TBLT as outlined above are met, the addendum 'competence' is redundant. This task type was originally not explicitly designed for integrating digital media; however, it can be woven seamlessly into the concept, making the tasks digitally-mediated according to our definition above, as we will show later. But first of all, we have to ask: what makes this task type complex and how can it be adapted to the specific circumstances of primary school? ${ }^{7}$

If we want to understand why Hallet's task type is called 'complex', it makes sense to have a look at an older typology of tasks by Legutke (2009, pp. 94). He differentiates between four 'communicative task types': 1. language learning tasks, 2. pre- 
communicative tasks, 3. communicative tasks and instrumental tasks and 4. management tasks. The level of difficulty increases from type 1 to type 4. However, as Hallet notes, the main focus and aim of all these tasks is to foster communicative competence. While this is, of course, also an aim of the complex task, its overall goal goes further: it aims at making learners active participants in cultural discourses. Consequently, complex tasks are oriented towards real-life problems, and while other constituents make up the complexity overall, problem orientation is the most crucial aspect of it. The 'complex' in its title thus refers to "an attempt to model the complexities and demands of lifeworld problem-solving in the language classroom" (Hallet \& Legutke, 2013, p. 151).

When it gets to problem orientation in the context of TBLT, there seem to be diverging opinions as to whether this type of orientation belongs to crucial elements of a task or not. Referring to Pattison's typology (1987), Nunan mentions problem-solving as a component in task and activity types that require learners to "make guesses, draw on their general knowledge and personal experience, use their imagination and test their power of logical reasoning." (Nunan, 2004, p. 54) Similarly, in his task typology of pedagogical tasks, Richards (2001) proposes that in problem-solving tasks "[s]tudents are given a problem and a set of information. They must arrive at a solution to the problem. There is generally a single resolution of the outcome" (Richards, 2001 as cited by Nunan, 2004, p. 59).

In the present context, we understand problem orientation as a phenomenon which appears at the beginning of a task and in which the learners have to solve the problem based on their own (for example, cognitive, linguistic, motivational, imaginative) resources. In contrast to Richards' above-mentioned definition of problem-solving tasks, this results not in a single task outcome, but in individual and ideally multimodal and creative task outcomes that bear the 'fingerprint' of the learners, as mentioned in the last section.

Furthermore, the complexity of the task is based on the fact that the task itself includes several other task types (e.g., the ones Legutke, 2009, defined, see above) and thus consists of a bundle of different challenges the learners have to face. They experience the task as a multidimensional sequence of individual cognitive, social, cooperative and interactive activities which gives them as much independence and autonomy in the learning process as possible (Hallet, 2011, p. 151).

Overall, the complex task is an attempt to combine the advantages and positive features of the TBLT approach, such as its openness and especially its authentic connection to pupils' lives and interests, with "the more recent developments and curricular frameworks that require definitions of learning outcome and can-do expectations." (Hallet \& Legutke, 2013, p. 151) This is why we think this model is a suitable approach for the foreign language classroom.

One important point has to be mentioned here: 'complex' does not mean 'difficult' (cf. Hallet, 2013, p. 10). The complexity of a task can and has to be, adjusted to the learners' individual level. A complex task can be problem-oriented and involve different sub-tasks and still be used in the early stages of foreign language learning. This helps to cumulatively build up literacies, starting as early as primary school. 


\section{Figure 1}

Model of the complex task according to Hallet (2011, p. 153)

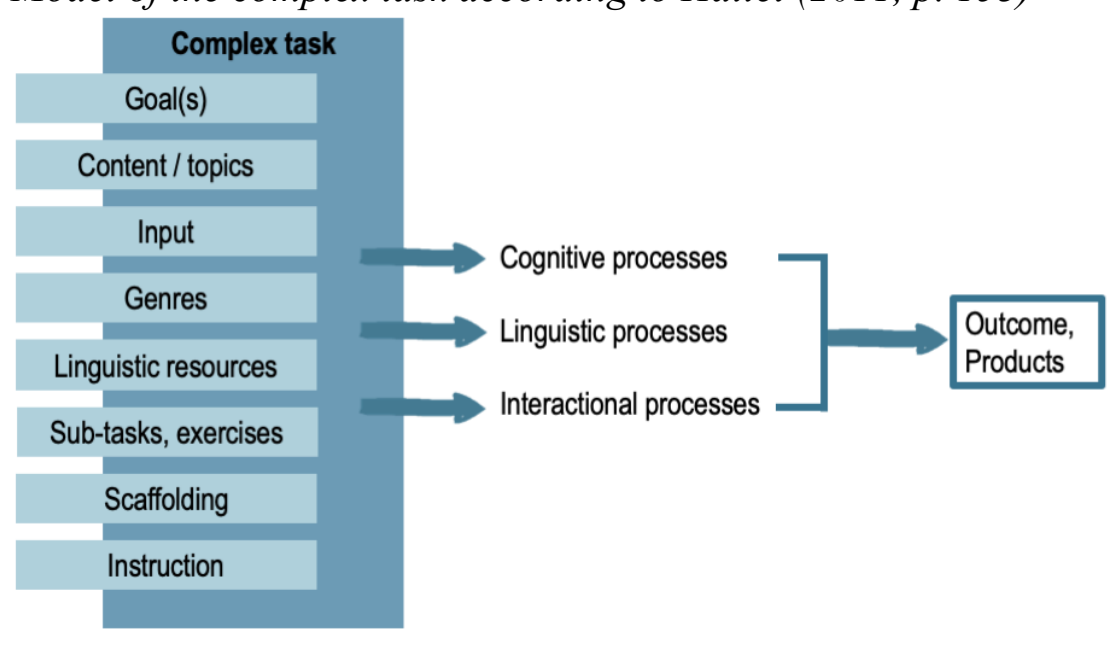

We will now have a closer look at Hallet's model of the complex task. The complex task consists of several 'ingredients' which can be used to differentiate the level of complexity (cf. Hallet, 2011, pp. 154 for a detailed description of the model's elements):

- Goal(s): Usually, there is one overall goal and several smaller goals that the learners are supposed to achieve.

- Content/topics: The content/topics of a complex task are oriented towards real-life problems and challenges thus, it is a central component of the task's complexity. This allows the learners to approach the task based on their own individual knowledge and experiences and opens up distinct ways of interpretation.

- Input: The input that is provided with the task should be diverse and multimodal. Not only can different channels of perception be reached, it also allows different learner types to approach the task in individual ways.

- Genres: The genres of the input material also serve as generic models for the learners' outcomes and are an important scaffold in solving the sub-tasks as well as the overall task. Depending on the learning level, it makes sense to also provide a set of rules for each genre that is involved (e.g., a "how-to" guide, or bullet points with the most important features of the respective genre).

- Linguistic resources: These include scaffolds that cannot be underestimated. The teacher needs to offer several types of linguistic resources that cater to the individual language level of the learners and acknowledges their individual language abilities.

- Sub-tasks, exercises: The sub-tasks and exercises involved in the complex tasks are oriented towards the overall tasks as well as the individual needs of the learners. Ideally, each learner only has to complete the sub-tasks/exercises that they need for solving the overall task.

- Scaffolding: Congruent to the principles of TBLT, scaffolding needs to be offered at every stage of the complex task (cf. section "Digital Media and TBLT"). 
- Instruction: While maintaining a maximum amount of learner autonomy, the instructions have to be clear and accessible at all times, making sure that also slower learners can solve the task independently.

In solving the tasks, different processes will be triggered, and as educators, we have to be aware of the differences between them, know their benefits and challenges with respect to the learning process and be able to anticipate them. Specific ways of dealing with the working process as a whole and different levels of engagement have to be provided, and also opportunities to work independently as well as cooperatively. The processes are closely linked to each other, and none is possible without the others, yet Hallet differentiates them into cognitive processes (i.e., the content the learners are supposed to understand/learn/realize), linguistic processes (i.e., the linguistic forms the learners will use to communicate and discuss), and interactional processes (i.e., the social constellations in which they are supposed to work [alone, in pairs, in groups]).

Finally, there is the outcome of the complex tasks, i.e., the learners' product(s). This outcome can be action- or production-oriented, as long as "outcome" is clearly defined. However, 'clearly defined' does not mean that there is only one correct outcome: what has to be clearly defined is the context (what are the content, time, and/or spatial coherencies), use (how can the outcome be applied), and function (what is the purpose of the outcome), but not what the end product is supposed to look like exactly. This openness allows for a high degree of differentiation and individualization. In true TBLT fashion, learners can solve the task according to their abilities and interests.

Coming back to the assumption that the complexity in the complex task can be adjusted according to the needs of the learning group, we now have to ask how this can be done for the primary school classroom. The fact that EFL learners in primary school obviously have limitations when it comes to vocabulary and grammar, but also knowledge and experience, makes the aforementioned aspect of problem orientation even more important - we have to choose 'problems' that are relevant to the real world of the learners while, at the same time, not overburdening them. Also, the elements of the task have to be modified in a way that fits the certain needs and prerequisites of primary school learning. Furthermore, the aspect of scaffolding becomes even more important, as we have to cater to the limited language resources of the primary school students in an adequate way. If we also keep in mind that there is not one single task outcome, but individual and ideally multimodal task outcomes, we can include the ideas from section 3 about the benefits of using digital media in the context of TBLT, resulting in complex digitally-mediated tasks. We will now try and illustrate these theoretical deliberations in a practical example, i.e., a task that was developed for and tested with learners in a primary school setting. The task is called "Animal Safari” (cf. Figure 3).

The product and ultimate outcome of the task is an animated role-play in which two animals from different continents meet. While this might seem far removed from the daily lives of the learners, the real-life problem orientation becomes apparent when we take a closer look at the elements of the outcome and the task. The context of the outcome, thus, is a (fictional) meeting, the use is the communication pattern of introducing oneself, and the function is knowing and applying the pattern. The task's goals are learning about animals, fostering digital literacy and learning to introduce oneself to someone else especially the latter two goals are as close to the daily lives of the learners as it gets, as 
they have to learn how to meaningfully interact with digital media (cf. section "Digital Media and TBLT") and be able to introduce themselves as a basic component of everyday conversations. The task and its sub-tasks, thus, are modelled according to real-life problem- and interaction situations, albeit with animals as more or less exotic 'protagonists'. In order to be able to create the final outcome, the learners solve two subtasks in preparation. In all parts of the task, digital media are used, as the learners work with iPads and different apps. Of course, 'analogue' material is used as well, for it is a wrong assumption that digitally-mediated tasks use nothing but digital media - just as in daily interactions, there is an interplay of digital and analogue media (Caruso, 2020).

First, the learners complete a vocabulary-focused task in which they practice the animals' names. The app BitsBoard can be used for this as it allows the users to create their own vocabulary cards and then practice the vocabulary with a set of games such as "pairs" (match the picture with the correct word) or multiple-choice quizzes (choose the correct word for the picture that is shown). A useful feature of the app is that the learners can choose how many words they want to practice and how they want to design the vocabulary cards (drawings, pictures). They can also record the pronunciation of the word, which is a major advantage compared to analogue vocabulary cards. In addition, valuable learning time can be saved when vocabulary cards are created and repeated digitally, not to mention the fact that they do not get lost as easily as analogue cards. Speaking in Nunan's (2004) terms, this first step serves as schema building activity, in which some key terms are introduced that pupils need in order to complete the task. Strictly speaking, this is more of an exercise than a sub-task, as the main goal is to learn and repeat the animals' names; the communicative aspects of a good task are neglected here. However, with regard to the openness of the possible result, some characteristics of a task are, in fact, given: It is up to the learners' interests and abilities how many vocabulary cards they choose to create, how they want to create them (e.g., add sound or not), and how thoroughly they want to use the in-app games.

Figure 2

Examples of the apps
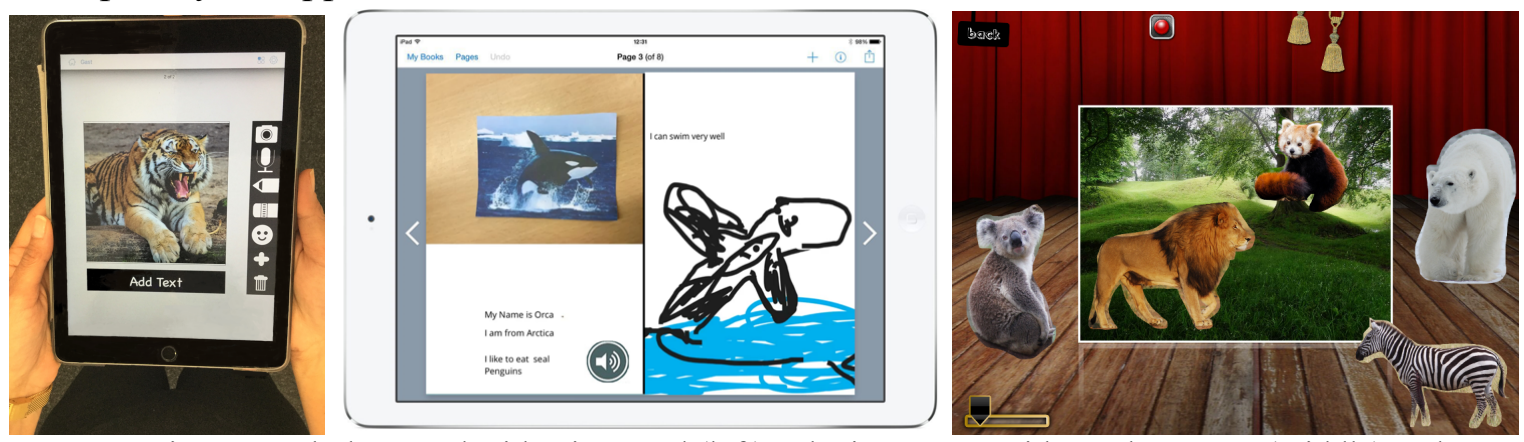

Note. Creating a vocabulary card with BitsBoard (left), a lexicon entry with Book Creator (middle) and an animated role play with Puppet Pals (right)

In a subsequent step, the learners create a simplified lexicon entry of an animal of their choice with the app Book Creator. It is important to note that this entry is simplified (by using the first person singular in describing the animal and only mentioning a few facts about it), but it still adheres to the main genre conventions of a lexicon entry - that is, it uses a picture, mentions the name of the animal and key facts about it (e.g., habitat, 
nutrition, enemies). Again, the learners can choose how detailed their lexicon entry will be according to their own level of language proficiency. Book Creator allows for the integration of text, images, sounds, hyperlinks, and videos. Thus, an authentic-looking, multimodal lexicon entry can be created easily. With the help of provided scaffolding, for example, in the form of chunks for the facts that can be used (e.g. My name is ... I live in ... My favourite food is... I like...) or model lexicon entries that can be used as generic prototypes, the pupils can compose their digital dictionary entries (see fig. 4, second picture).

The two sub-tasks enable the learners to create their own scaffolding for the animated role-play in which two animals meet and introduce themselves to each other. As stated above, the conversation pattern of introducing oneself is among the basic communicative principles in primary school and is introduced as early as first grade (KMK, 2008, p. 78). With the app Puppet Pals, the learners can create a playful, creative version of this pattern and, at the same time, become familiar with an easy way of producing a short, animated film. The fact that they transform a simplified lexicon entry into a conversation is a way to playfully focus on grammatical issues such as simple questions and answers (Do you like..? - No, I don't like.../Yes, I like...). They can practice and record their dialogue several times and do not have to expose themselves in front of the whole class when presenting it, thus allowing also more introverted learners to present their outcome. Also, they can easily show their product to their parents if they want to. In the context of the recently enforced homeschooling and digital teaching concepts in times of the COVID-19 pandemic, these digital task results can be easily sent to the teachers or shared with the whole class in virtual classroom settings (via Zoom, Microsoft Teams etc.).

\section{Figure 3}

Model of the complex digitally-mediated task "Animal Safari"

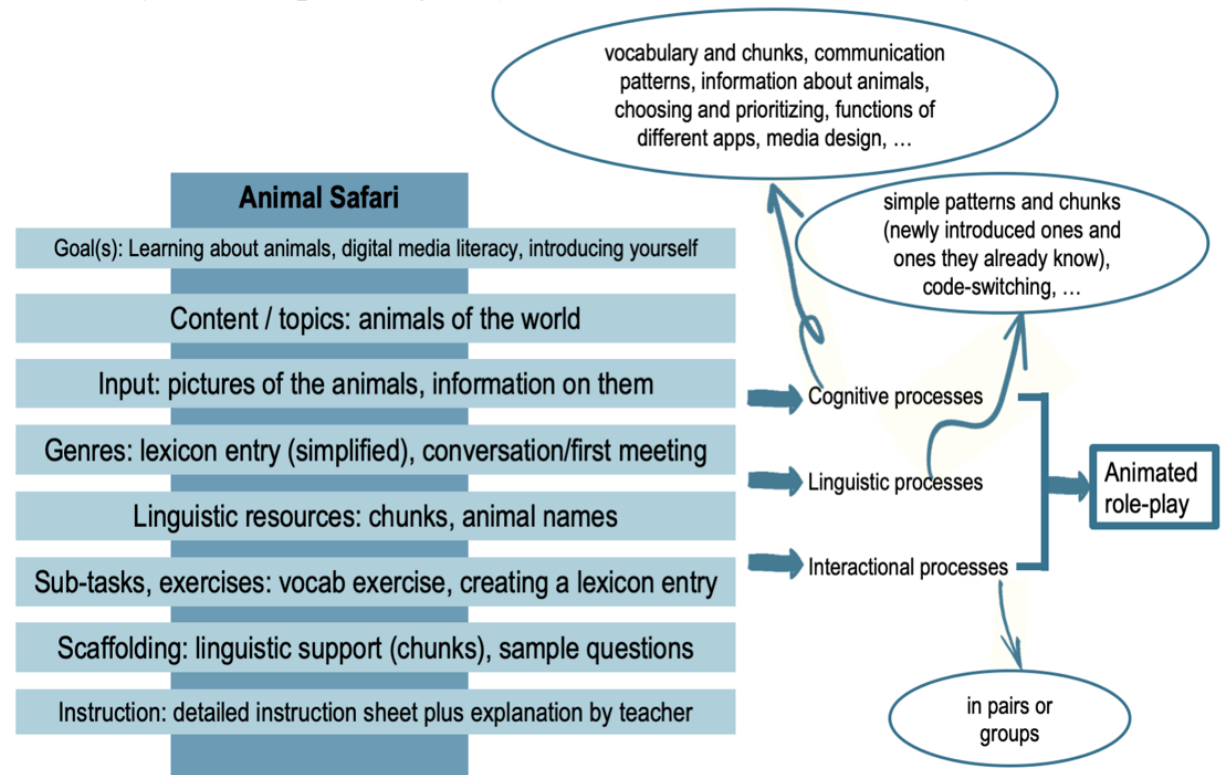

Note. In figure 3, the theoretical aspects of the complex task are put into more concrete terms, making it possible to grasp the function of the single components in the overall task.

In one of our university seminars, students tested this task in a primary school classroom. This was organized as a project day, but the task can easily be managed in 
several lessons. During the project day, there were different tables in the classroom, each one representing one continent with its specific animals. The class was divided into as many groups as there are continents, and the pupils became 'animal experts' for their continent. For the animated role-play, the groups were mixed again, making sure that there was at least one animal expert for each continent represented so that two animals from different continents were able to meet up in the role-play (authentic task outcomes from the project day can be seen in Figure 2). The informal feedback we received after the project day, both from the pupils and the regular teachers, was positive, and we continue to work with the school on similar project days, as the seminar is a regular part of our teacher training curriculum.

During all of the steps, there has to be clear instruction and the teacher has to be available for help if needed. Strictly speaking, this task does not allow an individual choice of sub-tasks/exercises as a 'true' complex task should. The learners can, however, choose how they want to work on the sub-tasks. There is a fine line between giving the learners a range of sub-tasks to choose from and overburdening them with choices. Especially in primary school TEFL, the teacher has to repeatedly review the most appropriate implementation for a particular learning group at a certain point in time. The task thus serves as a good practice example, but apparently can and should be adapted to the specific needs of the teacher and learners. It does, however, show that one complex digitallymediated task can be adjusted for primary school TEFL. This helps the learners to familiarize themselves with the problem-oriented tasks they will encounter during secondary school. Ideally, of course, tasks that focus on meaning and playfully approach a focus on form(s) should be used more often especially right at the beginning of secondary school, addressing the challenge of continuity of instruction at the transition to secondary schools that both learners and teachers are currently still facing.

\section{Conclusion}

In our paper, we tried to tackle two challenges of TEFL: firstly, the diverging teaching approaches in primary (mainly meaning-focused) and secondary (form-focused) level, and secondly the ways to deal with, as well as the consequences of, the digital transformation of EFL teaching by introducing the concept of complex digitally-mediated tasks.

While maintaining and elaborating on the main criteria of TBLT and a 'welldesigned' task, digitally-mediated tasks can serve as a tool to foster digital literacy as well as linguistic competences at the same time. When implemented in both primary and secondary contexts, complex digitally-mediated tasks can help bridge the gap between primary and secondary school EFL methodology, taking into account the issue of the lacking "[c]ontinuity of instruction at the transition to secondary level" (Baumert, 2020, p.32) addressed earlier in this paper.

If complex digital tasks are introduced as early as in primary school, pupils will already be familiar with the challenges these tasks entail and they will have developed strategies to solve them on the basis of their constantly developing linguistic, digital, and other literacies. They can profit from their experiences with task components such as problem orientation, digital possibilities of help-structures (scaffolding), and confrontation

with authentic material from the digital world, which can be elaborated on in the following 
school years. This will help learners with the transition from primary to secondary schools - thus, complex digital tasks have the potential to literally be bridging tasks.

An argument that is often used against the integration of digital media into the (EFL) classroom - no matter if it's in primary or secondary schools - is the lack of evidence that it is really 'worth it' to use tools other than the traditional, paper- or chalkbased media. The problem, however, is not only are there not many empirical studies on the fostering of digital literacies yet, but studies that already exist try and test the results of learning with digital media through analogue ways of testing. Not surprisingly, the results of these studies are often disappointing (Krommer, 2018). The question that we want to raise here is, then, if rather than calling for empirical evidence, shouldn't we first re-think how (and maybe even if) digital literacy can be tested?

It is necessary to keep in mind that digital media do not automatically improve the EFL teaching/learning and digitally mediated tasks are not 'better' than non-digital tasks. The digital world rather proposes authentic ways to include English as a foreign language into the classroom while, at the same time addressing aspects of digital competence.

With the presented concept of complex digitally-mediated tasks and the example of an EFL primary school task, not all of the challenges connected to digitalized learning can be addressed. It proposes nonetheless an approach of how to foster more concretely, single sub-components of the highly complex concept of digital competences, such as those proposed by the DigCompEdu (Redecker, 2017). The nature and content of the task itself determines which of those sub-competences are ultimately addressed: depending on their goals and design, different digitally-mediated tasks may target completely different puzzle pieces that finally contribute to both the linguistic and digital competence of the learners.

Correspondence should be addressed to Celestine Caruso, Judith Hofmann and Andreas Rohde . Emails: ccaruso@uni-koeln.de; judith.hofmann@uni-koeln.de; arohde@uni-koeln.de

\section{Notes}

${ }^{1}$ The difference between a "focus on forms" vs. a "focus on form" usually is that the former focuses on every grammatical form, making sure that the students pay attention to each individual grammatical phenomenon in grammatical instruction. "In focus on form instruction, attention to form arises out of meaning-centred activity derived from the performance of a communicative task.” (Ellis, 2008, p. 255).

${ }^{2}$ We do acknowledge that ELT in German secondary schools is still nowhere near a taskbased curriculum; this, however, is a challenge we are not going to address in this paper.

${ }^{3}$ There is no unified educational system in Germany, thereby making education a complex matter as it is predominantly the task of each individual federal state to oversee its own system. Each of the federal states has its own school system, its own curricula as well as teaching training and development agendas. (Wilden \& Porsch, 2020, p. 193).

${ }^{4}$ In North Rhine-Westphalia, it is actually the first three and a half years to be precise as $\mathrm{EFL}$ is introduced in the second half of the first year. 
${ }^{5}$ Note that, along the same lines, successful evaluations of early bilingualism in the form of immersion kindergarten/preschool programmes have not convinced policymakers to foster early foreign language learning to a stronger degree (Kersten et al., 2010a, 2010b).

${ }^{6}$ In the context of TEFL in Germany, both literacy and competence/competences are used when it comes to describing the goals of TEFL. While competence/competences refer/s to a more output-oriented idea of learning, literacy comes closer to the German term Bildung, i.e., a more encompassing, wholesome concept than a set of skills and accumulation of, knowledge. It includes subject mastery as well as aspects of personal and cultural maturation. Furthermore, literacy "is based on the assumption that acquiring subjectspecific knowledge is largely connected with the ability to express it in discursive form." (Hallet, 2009, p. 1)

${ }^{7}$ Defining the term 'complexity' is a complex matter in itself. We will try to elaborate on why we think Hallet's notion of the complex task is suitable for EFL, but for other definitions see Robinson (2001), or Nunan (2004, p. 85).

\section{Acknowledgements}

The project Future Strategy for Teacher Education is a part of the "Qualitätsoffensive Lehrerbildung" ('teacher training quality campaign'), a joint initiative of the Federal Government and the Länder that aims to improve the quality of teacher training. The program is funded by the German Federal Ministry of Education and Research. The authors are responsible for the content of this publication.

Celestine Caruso: https://orcid.org/0000-0003-0854-4558

Judith Hofmann: https://orcid.org/0000-0001-5484-6413

\section{References}

Appel, J. (2000). Erfahrungswissen und Fremdsprachendidaktik. Langenscheidt-Longman. Baumert, J., Fleckenstein, J., Leucht, M., Köller, O. \& Möller, J. (2020). The long-term proficiency of early, middle and late starters learning English as a foreign language at school: A narrative review and empirical study. Language Learning, 1-45. https://doi.org/10.1111/lang.12414

Biebighäuser, K., Zibelius, M. \& Schmidt, T. (2012). Aufgaben 2.0 - Aufgabenorientierung beim Fremdsprachenlernen mit Digitalen Medien. In K. Biebighäuser, K. Zibelius \& T. Schmidt (Eds.), Aufgaben 2.0 - Konzepte, Materialien und Methoden für das Fremdsprachen-Lehren und-Lernen mit digitalen Medien (pp. 11-56). Narr.

BIG-Kreis (Eds.). (2015). Der Lernstand im Englischunterricht am Ende von Klasse 4. Ergebnisse der BIG-Studie. Domino.

Böttger, H. (2009). Englischunterricht in der 5. Klasse an Realschulen und Gymnasien. Eine qualitative Studie zur Behandlung der Ergebnisse des Englischunterrichts in der Grundschule im bayerischen Schulsystem. Schulpädagogische Untersuchungen Nürnberg, 33, 1-52. 
Cameron, L. (2001). Teaching languages to young learners. Cambridge University Press. https://doi.org/10.1017/CBO9780511733109

Carless, D. (2002). Implementing task-based learning with young learners. English Language Teaching Journal, 56(4), 389-396.

Carless, D. (2004). Issues in teachers' re-interpretation of a task-based innovation in primary schools. TESOL Quarterly, 38(4), 639-662.

Caruso, C. (2020). Animals, Apps and Language Learning. Digitale Lernaufgaben für die Grundschule. Grundschulmagazin Englisch 2/2020, 32-35.

Dausend, H. \& Nickel, S. (2017). Tablets im Englischunterricht - Kompetenzen differenziert fördern und beurteilen. In S. Chilla \& K. Vogt (Eds.), Heterogenität und Diversität im Englischunterricht - fachdidaktische Perspektiven (pp. 179-203). Peter Lang.

DESI-Konsortium (2008). Unterricht und Kompetenzerwerb in Deutsch und Englisch. Ergebnisse der DESI-Studie. Beltz.

DIVISI [Deutsches Institut für Vertrauten im Internet] (2018) Euphorie war gestern. Die „, Generation Internet" zwischen Glück und Abhängigkeit. https://www.divsi.de/publikationen/studien/divsi-u25-studie-euphorie-war-gestern/

Dreßler, C. (2018). Nature and Enactment of Tasks for Early English as A Foreign Language Teaching: A Collaborative Teaching Project with Teachers. Narr.

Ellis, R. (2008). The Study of Second Language Acquisition (2 ${ }^{\text {nd }}$ ed.). Oxford University Press.

Ellis, R. (2018). Reflections on Task-Based Language Teaching. Multilingual Matters. https://doi.org/10.21832/9781788920148

Ellis, R., Basturkmen, H., \& Loewen, S. (2002). Doing focus-on-form. System 30, 419432. https://doi.org/10.1016/S0346-251X(02)00047-7

Elsner, D. (2015). Kompetenzorientiert unterrichten in der Grundschule: Englisch 1.-4. Schuljahr. Oldenbourg.

Gibbons, P. (2002). Scaffolding Language, Scaffolding Learning. Teaching Second Language Learners in the Mainstream Classroom. Heinemann.

González-Lloret, M. \& Ortega, L. (2014). Towards Technology-Mediated TBLT: An Introduction. In M. Gozález-Lloret \& L. Ortega (Eds.), Technology mediated TBLT: Researching Technology and Tasks (pp. 1-22). John Benjamins Publishing Company.

Hallet, W. (2009). Semiotic Translation, Literacy Learning and Teacher Development. In Proceedings of CLIL across contexts: A scaffolding framework for CLIL teacher education (pp. 1-3). Université de Luxembourg. https://languagelearninglog.de/wpcontent/uploads/2018/02/180218_2009_HALLET_Semiotic_Translation_Teacher_ Education.pdf

Hallet, W. (2011). Lernen fördern: Englisch. Kompetenzorientierter Unterricht in der Sekundarstufe I. Kallmeyer/Klett.

Hallet, W. (2012). Die komplexe Kompetenzaufgabe: Fremdsprachige Diskursfähigkeit als kulturelle Teilhabe und Unterrichtspraxis. In W. Hallet \& U. Krämer (Eds.), Kompetenzaufgaben im Englischunterricht. Grundlagen und Unterrichtsbeispiele (pp. 8-19). Klett Kallmeyer.

Hallet, W. (2013). Differenziert arbeiten mit der Kompetenzaufgabe. Der fremdsprachliche Unterricht Englisch, 124/2013, 10-11 
Hallet, W. \& Legutke, M.K. (2013). Task-Approaches Revisited. New Orientations, New Perspectives. The European Journal of Applied Linguistics and TEFL 2/2013, 139158.

Hempel, M., Kötter, M., \& Rymarczyk, J. (2018). Fremdsprachenunterricht in der Grundschule in den Bundesländern Deutschlands. Peter Lang.

Hofmann, J. (2018). Komplexe Lernaufgaben für die Grundschule - Working with Animated Films. Grundschulmagazin Englisch 4/2018, 31-34.

Jaekel, N., Schurig, M., Florian, M. \& Ritter, M. (2017a). From early starters to late finishers? A longitudinal study of early foreign language learning in school. Language Learning, 67, 631-664.

Jaekel, N., van Ackern, I., Schurig, M. \& Ritter, M. (2017b). Zeigt der Frühbeginn seinen langen Atem? Der Frühbeginn in Klasse 1 und 3 und sein Einfluss auf die Englischkompetenz in Klasse 9. Paper presented at the 29th DGFF Conference. Jena, 27-30 September 2017.

Jenkins, H., Purushotma, R., Weigel, M., Clinton, K. \& Robison, A.J. (2009). Confronting the Challenges of Participatory Culture. Media Education for the 21st Century. MIT Press.

Kersten, K., Rohde, A., Schelletter, C. \& Steinlen, A. K. (2010a). Bilingual Preschools. Volume 1: Learning and Development. Wissenschaftlicher Verlag Trier.

Kersten, K., Rohde, A., Schelletter, C. \& Steinlen, A. K. (2010b). Bilingual Preschools. Volume 2: Best Practices. Wissenschaftlicher Verlag Trier.

KMK (2005). Bildungsstandards für die erste Fremdsprache (Englisch/Französisch) für den Hauptschulabschluss: Sekretariat der Ständigen Konferenz der Kultusminister der Länder in der Bundesrepublik Deutschland. Luchterhand/Wolters Kluwer.

KMK (2008). Lehrplan Englisch für die Grundschulen des Landes Nordrhein Westphalen. https://www.schulentwicklung.nrw.de/lehrplaene/upload/klp_gs/LP_GS_2008.pdf

KMK (2016). Bildung in der digitalen Welt. Strategie der Kultusministerkonferenz. https://www.kmk.org/aktuelles/thema-2016-bildung-in-der-digitalen-welt.htm

Kolb, A. (2011). Kontinuität und Brüche - der Übergang von der Primar- zur Sekundarstufe aus der Perspektive der Lehrkräfte. Zeitschrift für Fremdsprachenforschung, 1, 145-175.

Kolb, A., Mayer, N. \& Stotz, D. (2012). The story goes on - Kontinuität durch Kooperation. Grundschulmagazin Englisch, 6/2012, 9-12.

Kolb, A. \& Legutke, M. (2019). Englisch ab Klasse 1. Anmerkungen zu einer bildungspolitischen Diskussion. In A. Kolb \& M. Legutke (Eds.), Englisch ab Klasse 1-Grundlage für kontinuierliches Fremdsprachenlernen (pp. 7-19). Narr, Francke, Attempto.

Krommer, A. (2018). Wider den Mehrwert! Oder: Argumente gegen einen überflüssigen Begriff. https://axelkrommer.com/2018/09/05/wider-den-mehrwert-oder-argumentegegen-einen-ueberfluessigen-begriff/

Legutke (2009). Lernwelt Klassenzimmer. Szenarien für einen handlungsorientierten Fremdsprachenunterricht. In G. Bach \& J.-P. Timm (Eds.), Englischunterricht. Grundlagen und Methoden einer handlungsorientierten Unterrichtspraxis (4th ed., pp. 91-120). Francke.

Mayer, N., Kolb, A. \& Stotz, D. (2012). Bridging Tasks - Kontinuität zwischen den Schulstufen. Grundschulmagazin Englisch, 6/2012, 7-8. 
Müller, T. (2017). Einflussfaktoren auf den Lernkontext im Fach Englisch am Ende von Klasse 4. Aspekte der vertieften Auswertung der BIG-Studie 2013. Herne: Gabriele Schäfer Verlag.

Müller-Hartmann, A. \& Schocker, M. (2018). The challenges of integrating focus on form within tasks. In V. Samuda, K. Van den Branden \& M. Bygate (Eds.), TBLT as a Researched Pedagogy (pp. 98-129). John Benjamins Publishing Company. https://doi.org/10.1075/tblt.12

Muñoz, C., Tragant, E., \& Camuñas, M. (2015). Transition: Continuity or a fresh start? APAC Quarterly, 89, 11-16.

MSW-NRW (2007). Kernlehrplan für den verkürzten Bildungsgang des Gymnasiums Sekundarstufe I (G8) in Nordrhein-Westfalen. Ritterbach Verlag.

Niemeier, S. (2017). Task-based grammar teaching of English. Where cognitive grammar and task-based language teaching meet. Narr, Francke, Attempto.

Nunan, D. (2004). Task-Based Language Teaching. Cambridge University Press. https://doi.org/10.1017/CBO9780511667336

O’Brien, D. \& Scharber, C. (2008). Digital Literacies. Journal of Adolescent and Adult Literacy 52(1), 66-68.

Pattison, P. (1987). Developing Communication Skills. Cambridge University Press.

Pienemann, M. (2006). Spracherwerb in der Schule: Was in den Köpfen der Kinder vorgeht. In M. Pienemann, J.-U. Keßler \& E. Roos (Eds.), Englischerwerb in der Grundschule (pp. 33-63). Paderborn et al.

QUA-Lis NRW (2008). Didaktisch-methodische Fortbildung Englisch in der Grundschule. Modul 8: Kompetenzorientiert Unterricht planen.

https://www.schulentwicklung.nrw.de/cms/upload/egs/Modul_8_Kompetenzorienti ert_Unterricht_planen.pdf

QUA-Lis NRW (2020). Task-Based Learning. https:/www.schulentwicklung.nrw.de/cms/angebote/egs/didaktik-und-methodikim-egs/kompetenzorientierte-planung-und-gestaltung-des-unterrichts/task-basedlearning.

Redecker, C. (2017). European framework for the digital competence of educators: DigCompEdu (No. JRC107466). Joint Research Centre (Seville site).

Reiss, K., Weis, M., Klieme, E. \& Köller, O. (2019). PISA 2018. Grundbildung im internationalen Vergleich. Zusammenfassung. Waxmann.

Richards, J. C. (2001). Curriculum Development in Language Teaching. Cambridge University Press.

Robinson, P. (2001). Task Complexity, Task Difficulty, and Task Production: Exploring Interactions in a Componential Framework. Applied Linguistics, 22 (1), 27-57.

Rohde, A. (2016). Who is the competent language learner? Kompetenzorientierung revisited. Grundschulmagazin Englisch, 3/2016, 37-38.

Rohde, A., Caruso, C., Hofmann, J. \& Schäfer, U. (2018). Übergang von der Primar- zur Sekundarstufe: The difficult path from meaning to form. Grundschulmagazin Englisch, 1/2018, 31-34.

Schmid, U., Goertz, L. \& Behrens, J. (2017). Monitor Digitale Bildung. Die Schule im digitalen Zeitalter. Bertelsmann Stiftung. https:/www.bertelsmannstiftung.de/fileadmin/files/BSt/Publikationen/GrauePublikationen/BSt_MDB3_Sch ulen_web.pdf 
Thaler, E. (2012). Englisch unterrichten. Grundlagen - Kompetenzen-Methoden. Cornelsen.

Wilden, E. \& Porsch, R. (2020). A critical analysis of the German public debate about an early start in primary foreign language education. Language Teaching for Young Learners, 2(2), 192-212. https://doi.org/10.1075/1tyl.19019.wil

Zerweck, B. (2009). Fernsehen und Schule. TV-Serien als trojanische Pferde des Schulunterrichts. In J.A. Sohns \& R. Utikal (Eds.), Popkultur trifft Schule. Bausteine für eine neue Medienerziehung (pp. 253-268). Beltz. 